Nóra I. Jakab, Ph.D., Associate Professor University of Miskolc

Faculty of Law

jakabn81@gmail.com

\title{
THE IMPORTANCE OF INDIVIDUAL SELF-GOVERNANCE IN LABOUR LAW*
}

Abstract: According to László Kelemen, a contract is a lex contractus, a real source of law, when material right enables human self-determination to create law. In the field of civil law, this individual self-governance indeed widely prevails, whereby legal entities themselves shape the law to legally unregulated relations of life and to some parts of them which are not arranged. In labour law, the legislative power of individuals must be re-discovered in employment contracts, to which it is essential to enforce the principle of partnership.

Section 13 of the Labour Code also establishes a hierarchy of the rules on employment, and the said hierarchy is broken by the principle of more favourable treatment for the employee, which means relatively cogent and relatively dispositive rules in civil law. At the same time, the regulatory technique of the Labour Code clearly demonstrates a respect for the principle of freedom of contract and the promotion of self-governance.

The essay presents the thinking of Hungarian Labour Lawyers including the author on the nature of Labour Law. The author draws the attention to the principle of partner relationship within the Hungarian Labour Code, showing the opportunities in the Hungarian Labour Law regulation for flexibility.

Keywords: self determination in private and collective labour law, flexicurity, classification of work activities, branch law classification, unique system of norms.

\section{ON THE PUBLIC AND PRIVATE LAW ELEMENTS OF LABOUR LAW}

The essay focuses on the Hungarian Labour Law lawers' thinking on th labour law including the authou special view on the private labour law, ie. employment contract.

* This paper was supported by the János Bolyai Research Scholarship of the Hungarian Academy of Sciences. 
Károly Szladits says: "The characteristic feature of today's so-called public law development of private law is not an ever-increasing space of community thought or public interest coming to the front, but individual self-governance shrinking more and more noticeably and rather significant areas of the interrelationships of individuals becoming subjects of authority provisions, like e.g. in labour law." In modern labour law, therefore, the principle of freedom of contract does not apply to the same extent as in civil law due to the unequal position of the parties and state interference; the whole branch of law is interwoven with public law elements.

That is, the contractual nature of labour law cannot be discussed, but some parts of the rights and obligations of employment relationship are not determined by the contracting parties. ${ }^{2}$ Private labour law is manifestation of the opportunities for self-determination of the parties. Consequently, the basic principle of the private law is the so-called contractual principle. This means, in particular, that everyone has the opportunity to establish and shape their legal relationships through the regulation of self-determination. ${ }^{3}$ In addition, it is the legislator's duty to establish rules protecting the individual employee against the employer's power.

During the industrial revolution in the 18th and 19th century, the principles of private law and property law were applied to the labour market. First employment contracts were considered classic private contracts. Freedom of property was given absolute priority over employee interests. Keeping labour law clearly within private law, however, was unsustainable in the long term, since while the subjects of private law are parties in the market, the asymmetry between the employer and the employee is clear. ${ }^{4}$ The freedom of the worker's contract volition was only an illusion in the past centuries. The rampant pursuit of the employer's interest might have led to the vacancy of the labour contract, and today, I think, this can be considered a marginal problem of labour law regulation.

The protection of the weaker party and thus the limitation of contractual freedom have two paths: collective action and state intervention. ${ }^{5}$ In the order first the period of contractual freedom was followed by the gradual recognition of freedom of association, the period of collective bargaining agreements, entailing the power to convert the terms of individual employment contracts and the recognition of the extended scope for the legal relationship of non-organized members. The next stage is the period of state intervention when the state interferes in the

${ }^{1}$ László Kelemen, Obligation based on contract, (A szerződésen alapuló kötelem), Actio Universitatis Szegediensis. Sectio Iuridico-Politica Curant S. Ereky et E. Polner, A M. Kir. Ferenc József-Tudományegyetem Barátainak Egyesülete 1941, 17-18.

${ }^{2}$ See more: György Kiss: Labour Law, (Munkajog,) Budapest, Osiris 2005, 32-33.

${ }^{3}$ Ibid. 27.

${ }^{4}$ József Hajdú, Attila Kun, Labour Law I. (Munkajog I.), Budapest, Patrocínium 2011, 59.

${ }^{5}$ József Hajdú, Attila Kun (2011) 59. 
parties' private law relationship: in the case of industrial action, restricting working time, imposing accident-health protection requirements on the employer, imposing minimum wages. Standards protecting employees, however, do not mean the elimination of the base set by the law of obligation.

By World War II, labour law had been consolidated in most developed states. ${ }^{6}$ In the post World War II period general democratisation and the expansion of social function of the state started gaining ground. The social fundamental rights as elements of the second generation of human rights more and more often incorporated in the national constitutions started to become fundamental moral foundations of the so-called welfare or social state. Welfare states were mainly built on a fast-paced and long-term economic growth based on large scale, standardised mass production as well as the Keynesian demand-driven economic policy. The economic model dating back to the 1920s and experiencing the golden age later in the 1950s and 1970s is known as Fordism after Henry Ford. In this Fordist model, the representative employee a breadwinner father. The bureaucratic, monotonous, large-scale factories of large corporations based on the scientific management theory of Taylorism provided the main grounds for mass production. The classical institutions of labour law evolved in this socio-economic order over this period. In the 1970s, a new development of the social dimension of the European Union began including labour law. ${ }^{7}$ The development of today's labour law is, however, not determined by the social and economic order of Fordism. The labour market environment has changed. People are more likely to change jobs, fixed-term employment, seasonal work, and temporary employment have become common. Many have become self-employed, working time is changing flexibly, the nature of work has become more varied and flexible. ${ }^{8}$ Economic environment has also changed since we are now living in a knowledge-based society, and economy must go hand in hand with technological innovations and changing consumer demands. Employers must promptly respond to changes in tastes and create a work organization that can adapt effectively and quickly to changing needs. The question then rightfully arises if law is still responsible for creating work safety, or time has marched on so law must protect income and employability instead. ${ }^{9}$

\footnotetext{
${ }^{6}$ See more Ibid. 60-61.

${ }^{7}$ Ibid. 61.

${ }^{8}$ See: Senad Jašarević, "Flexible Work - Right Solution or Fallacy“, Collected papers Faculty of Law Novi Sad, 4/2012, 173-182

${ }^{9}$ On the changes of Labour Law see: S. Deakin, G. S. Morris, Labour Law, Sixth Edition. Hart Publishing, Oxford and Portland, Oregon 2012, 30-37. 131-190., Contract Labour - Fifth item on the agenda Report V (1) to the International Labour Conference 86th Session 1998, Geneva. S. Deakin, F. Wilkinson, The Law of the Labour Market. Industrialisation. Employment and Legal Evolution, Oxford University Press, Oxford 2005; R. Blainpain, F. Hendricks, European Labour Law, Kluwer Law International Bv, The Netherlands 2010; (eds. Guy Davidov, Brian Langille): The Idea of Labour law, Oxford University Press, Oxford 2011
} 
Labour law regulation has responded by the introduction of the concept of 'flexicurity'. ${ }^{10}$

The question of flexibility and security, however, involves addressing the problems of vulnerable groups. This poses basically two challenges for labour law: creating, if necessary, rules protecting employment and enforcing compliance with them.

Social exclusion refers to several groups that are unable to participate in the labour market, and therefore the objective is to increase employment rate through macroeconomic policies.

New regulatory techniques are also needed against the previous hierarchy and command-based system, for example, tax incentives for employees and the self-employed, operation of occupational pension schemes, employee shareholding, and transitional grants for economic operators employing long-term job-seekers.

New information and consultation mechanisms are needed which favour a partnership between the employer and the employees.

In addition, human rights struggles and globalization that have been intensifying since the second half of the century have a great impact on labour law.

In this development, in the changed economic and social environment it is obvious that at first it was impossible to keep employment relationship within private law, public law elements necessarily infiltrated. This, however, does not mean that labour law separated from private law. In the relationship between labour law and private law, initially identity was discernible, followed by some sort of distancing and finally approaching again. Labour law moved away from private law until the 1970s, but since then it has been getting closer and closer. Therefore when reading György Kiss ${ }^{11}$ about the importance of the consensus of the parties in shaping the relationship of employment, this approach must be understood.

${ }^{10}$ See more: Auer Peter, Gazier Bernard: Social and labour market reforms: four agendas. In: (eds. Ralf Rogowski, Robert Salais, Noel Whiteside, Transforming European Employment Policy. Labour Market Transitions and the Promotion of Capability, Edward Elgar, Cheltenham, UK, Northampton, Ma, USA, 2011 33-37. Guidline 21 of the Integrated Guidelines for growth and jobs for the period 2005-2008: Promote flexibility, combined with employment security and reduce labour market segmentation, having due regard to the role of social partners. Guideline 7 of the Europe 2020 Integrated Guidelines for economic and employment policies of the Member States and of the Union.

11 See more: György Kiss: "Employment in Time of Economic Crisis - Opportunities in Labour Law to Change the Content of the Employment Relationship (Legal Dogmatic Basis and Law Policy)", ("Foglalkoztatás gazdasági válság idején - A munkajogban rejlő lehetőségek a munkajogviszony tartalmának alakítására (jogdogmatikai alapok és jogpolitikai indokok”), Állam-és Jogtudomány, 1/2014, 36., György Kiss: "Dilemmas of Labour Law Regulation”, (“A munkajog szabályozásának dilemma”), Miskolci Jogi Szemle Különszáma, 12/2017, (2), 273-274. 


\section{ON THE CLASSIFICATION OF WORK ACTIVITIES}

The place of labour law in private law is often explained by the classification of work activities. The classical forms of work performed for someone else include dependent work performed under a contract of employment (which constitutes human relations through labour), independent work performed under business contract (which constitutes human relations through market goods) and independent work performed under mandate. Dependent work performed under a contract of employment developed dogmatically in Roman law from the institution of consensual contract (locatio conductio). ${ }^{12}$

Accordingly, the demarcation of the employment relationship to this day is typically related to the institution of locatio conductio operis and mandate. Work performed for someone else is therefore expressed in three classical contracts, and by comparing them one finds why subordination of the employee is necessary in some cases of work performed for someone else and in other cases why not. ${ }^{13}$ Thus, the classification of employment relationships is basically based on the dual model of employee - self-employed relationship. In this comparison, the concepts of Selbst bestimmung and Fremd-bestimmung referred to by Kiss György, the former describing the legal relationship of engagement contracts and business contracts, the latter that of the employment contracts, reflect the basis for the fundamental dogmatic difference between legal relationships. ${ }^{14}$

At the same time, it is justified to mention György Kiss's opinion who draws attention to two criteria of employment relationship: its long-term nature and the employee's legal subordination. The long-term, durative nature, however, may be questioned by the existence of atypical employment relationships which funda-

12 Tamás Prugberger, György Nádas: European and Hungarian Comparative Labour and Public Administration Law, (Európai és magyar összehasonlitó munka-és közszolgálati jog), Wolters Kluwer, Budapest 2014, 27-31., (eds. József Hajdú, Attila Kun), Labour Law, (Munkajog), Budapest, Patrocinium 2014, 31-40.

${ }^{13}$ Tamás Prugberger: Labour Law in Civil Law among the globalised social relationships, (Munkajog a polgári jogban a globalizálódó társadalmi viszonyok között), Competitio Könyvek, Debreceni Egyetem Közgazdaságtudományi Kar 2006, 66-72.; György Kiss: The new Civil Code and the Labour Law Regulation with Special Regard to the Individual Employment Contract. (Az új Ptk. és a munkajogi szabályozás, különös tekintettel az egyéni munkaszerződésekre.) In: (eds. Manfred Ploetz, Hilda Tóth), Relationship between the Civil and Labour Law Codification. (A munkajog és a polgári jog kodifikációs és funkcionális összefüggései), Tanulmánykötet, Novotni Kiadó, Miskolc 2001, 198-199.; Tamás Prugberger, "Institution of Self-Employment in the Western European and Hungarian Labour Law”, (“Az önfoglalkoztatás intézménye a nyugat-európai és a magyar munkajogban”), Magyar Jog, 2/2014, 65-71. See more: S. Deakin, G. S. Morris (2012) 145. ff. H. Collins, K.D. Ewing, A. McColgan, Labour Law. Cambridge University Press, Cambridge 2012, 45-86.

${ }^{14}$ Staudinger, Richardi:Kommentar zum Bürgerlichen Gesetzbucs mit Einführungsgesetz und Nebengesetzen, Berlin, Walter de Gruyter (1989) 692-699. Cited by: György Kiss (2005) 19. 
mentally determined the development of labour law after World War II. The longterm, durative nature, however, must be deduced from the essential features of the employment relationship. The comparison is also based on the business and engagement contract. In a business contract, when the result is achieved, the contract terminates, extinguishes itself. Labour law also includes a contract for the performance of a particular task. Is there a difference? Apart from the difference between the content of the two legal relationships, the instructions of the customer and that of the employer, the principle and regulation of elimination are distinctly different. In the case of a business, settlement issues, while in the case of labour relations, the employee's existential interests arise. It is also the case if a particular activity can be performed in the framework of a contract and an employment relationship. In the same way, it is the intensity, scope and regulation of the termination that differ. Freedland approaches the long-term nature of employment relationship from the side of promise: the promise of further work. The existence of mutual promise may be justified by the protection against dismissal. The essence of these techniques is that employers should not keep an eye out for dismissal, but the maintenance of the employment relationship..$^{15}$

It is also necessary to discuss the classification of work performance relationships briefly. According to József Hajdú and Attila Kun, labour law is a set of legal norms defining the rights and obligations of employees, employers and interest representatives (social partners) from among legally regulated work-performance relationships. Its notion complex and regulates both economic and social conditions. ${ }^{16}$

According to Tamás Gyulavári, labour law deals with the legally regulated dependent work that is performed for someone else, under contract, under subordination. ${ }^{17}$ The dogmatic basis for the distinction between civil service and private employment relationship may be challenged in that both are legal expressions of dependent work. The quality of the party receiving the service is secondary. That is, in terms of the category of dependent work, civil service relationship is an employment relationship, as well. ${ }^{18}$

In a broader sense, therefore, labour law covers all legal relationships that are suitable for displaying dependent work performed for someone else. ${ }^{19}$ However, based on the current Hungarian tendencies, it is difficult to imagine that labour law continues to be used as a generic term and that division is made within this genus. The legal dogmatic foundation of collective labour law is possible in

\footnotetext{
${ }^{15}$ György Kiss (2017) 273-274.

16 József Hajdú, Attila Kun (2014) 31.

${ }^{17}$ Ibid. 67.

${ }^{18}$ György Kiss (2005) 22.

${ }^{19}$ See: Senad Jašarević, "Labour Relation - Tendencies in the Practice and in the Regulations “, Collected papers Faculty of Law Novi Sad, 3/2013, 242
} 
the private law of work; it is the result of a long-term development in civil service under external influence. ${ }^{20}$

In the system of employment relationships many differentiate employment relationship from civil service employment and other work performance relationships, including civil law relationship, other special legal relationships: personal and property security contractor, permanent intermediary, scholarship employment. All of this is a great expression of the legislator's intention to detach civil service from labour law and the question of employee-like persons' legal relationship..$^{21}$

In my own view, the horizontal demarcation of work-performance relationships may be based on personal and economic dependence, economic dependence as well as personal and economic independence. Moreover, vertical division within employment relationship can be interpreted to a less and less extent as a result of the detachment of civil service law from labour law. And there is the theory of personal work relations of Freedland and Countouris to discuss. ${ }^{22}$

${ }^{20}$ György Kiss (2005) 23. On the separation of public administration see: Attila Kun, Zoltán Petrovics, On the Development of Public Administration as a branch of Law, (A közszolgálati jog önálló jogági fejlődésének kérdéséről), Magyar Közlöny Lap- és Könyvkiadó, Budapest, Henriett Rab, 'Jurisdiction in Public Administration from HR's Point of View”, (“A közszolgálati bíráskodás HR szempontú vizsgálata”), Közjogi Szemle, 1/2016, 8-12. Gábor Mélypataki, Theoretical and Practical Issues of the Unification of Public Administration Law and Its Relationship with Private Labour Law, (A közszolgálat egységesitésének elméleti és gyakorlati problémái, és kapcsolata a munka magánjogával), PhD dissertation, Deák Ferenc Állam-és Jogtudományi Doktori Iskola, Gábor Mélypataki, "Defintition of employee in the Hungarian and German Labour Law from the employee's Point of View", ("A munkavállaló fogalma a magyar és a német jogban a munkáltató szempontjából)," Publicationes Universitatis Miskolciensis Series Juridica Et Politica XXX/2: p. 521.(2012)

21 On the employee like person see a great Hungarian literature: György Kiss, "A munkavállalóhoz hasonló jogállású személy problematikája az Európai Unióban és e jogállás szabályozásának hiánya a Munka Törvénykönyvében”, Jogtudományi Közlöny, 1/2013., 4-8., Tamás Prugberger, Az önfoglalkoztatás intézménye a nyugat-európai és a magyar munkajogban," Magyar Jog, 2/ 2014, 68-69., Tamás Gyulavári: “A gazdaságilag függő munkavégzés szabályozása: Kényszer vagy lehetőség?” Magyar Munkajog E-folyóirat, 1/2014, 17-20. Tamás Gyulavári: A szürke állomány. Gazdaságilag függő munkavégzés a munkaviszony és az önfoglalkoztatás határán, Jogtudományi Monográfiák 6. Pázmány Press, Budapest 2014, Bernadett Szekeres, “Gondolatok a munkavállalóhoz hasonló jogállású személyek helyzetéről - a munkajog és a polgári jog kapcsolatáról”, Miskolci Jogi Szemle: A Miskolci Egyetem Állam- és Jogtudományi Karának folyóirata, 12/2017, (2.) 561-569., NóraJakab: A munkavállalói jogalanyiság munkajogi és szociális jogi kérdései - Különös tekintettel a megváltozott munkaképességü és fogyatékos személyekre, Miskolc, Bíbor Kiadó 2014

22 On the personal work relationship see: M. Freedland, N. Countouris, The Legal Characterization of Personal Work Relations and the Idea of Labour Law. In: (eds. Guy Davidov, Brian Langille), The Idea of Labour law, Oxford University Press, Oxford 2011a; M. Freedland, N. Countouris, The Legal Construction of Personal Work Relations, Oxford University Press, Oxford, $2011 b$ 


\section{ON BRANCH LAW CLASSIFICATION}

We shall now briefly examine the branch law classification of labour law. Branch law classification in certain definitions raises the relationship with civil law and deals with a specific system of norms. In 2005, György Kiss wrote: "Over two centuries modern labour law has evolved from the simple lease contract to the law of individual and collective labour relations. In this process, labour law gradually detached itself from classical private law, but did not banish its principles and values altogether. ${ }^{23}$ In 2017 he wrote: "Today, it is recognized in Hungarian labour law as well that labour law as a contractual branch of law is a part of private law." 24

According to Tamás Prugberger labour law is one of the "private law-like" so-called mixed branches of law which are situated between public law and private law and which are amalgamated from elements of private law and public law..$^{25}$ According to József Hajdú and Attila Kun, labour law is the branch of a unified Hungarian legal system that governs the social relations (employment relationship) that relate to the employment of independent persons. Labour law is part of private law. Its social embeddedness, its purpose-orientedness is defined by the employee's demand for protection. Employment relationship is a long-term relationship in which the application of civil law rules is by no means problem-free. Labour law as a separate branch of law (mixed law) is not part of civil law, but they have a very close relationship. The Civil Code is in relation to the Labour Code subsidiary legislation, that is, the Labour Code specifies the cases in which Civil Code rules may and must be applied and when not. See Section 31 of the Labour Code ${ }^{26}$

György Kiss points out Bydlinsky's insightful summary opinion: the question is whether labour law can be placed in the legal system as an independent branch. In his view, the autonomy of labour law is relative. It is impossible to elaborate an independent contract doctrine for labour law. The independence of labour law is an extremely complex problem, because despite the fact that there are institutions which are only characteristic for labour law, the rules of civil law must be applied as either self-evidently or with minor modifications. However, it is important not to create unnecessary competition between the two branches of law. ${ }^{27}$ The formation of an independent labour law became the centre of political interest in the legislation of the Weimar Republic. After WWII, the German codification

${ }^{23}$ György Kiss (2005) 15.

${ }^{24}$ György Kiss (2017) 271.

25 Tamás Prugberger: European and Hungarian Comparative Labour and Public Administration Law, (Európai és magyar összehasonlitó munka-és közszolgálati jog), Budapest, KJK Kerszöv 2002, 33.

26 József Hajdú, Attila Kun (2014) 31.

27 György Kiss (2017) 271. 
managed to find solutions to the collective institutions, but failed to draft the legislation of the labour contracts. György Kiss often refers to the Hennsler-Preis draft: ,Soweit dieses Gesetz nicht anderes bestimmt, gelten die Bestimmungen des Bürgerlichen Gesetzbuches. "28

Recognition of the full independence of labour law from civil law, the full dogmatic autonomy of the institution has never been demanded. Undoubtedly, however, the dogmatic nature of the contract has not, but its function has been transformed in order to protect the employee. Due to these restrictive rules and the principles of traditional private law, the contractual institutional system of labour law seems to be autonomous. Principles outside private law are the principle of equal treatment, the duration of employment relationship, the regulation of termination of employment relationship. These principles are subject to attack because the structure of the legal relationship underlying them varies ${ }^{29}$ Consequently what distinctly separates individual labour law from traditional private law is the normative law designed to protect the worker through direct state intervention which developed predominantly outside private law codes. Labour law attempts to strike a balance at a level of equilibrium that meets the contractual principle, the requirements of self-determination..$^{30}$ In the socialist, public lawlike labour law, the application of civil law did not really arise. Socialist labour law broke up with the private law traditions of labour law. The Labour Code of 1992 contained a more private law-like regulation but failed to settle the relationship between labour law and civil law. In the judicial practice, the so-called principle of analogia legis got crystallised, that is if a civil law norm or principle is not contrary to labour law and if the Labour Code does not contain a specific provision, judicial practice may involve the given civil law rule in the labour law (pursuant to Court Decision 1998.506). Act I of 2012 on the Labour Code (Mt.) changed of the previous regulation and expressly marked the applicability of some rules of the Civil Code. According to Section 31 of the Labour Code, for example, in the case of legal declarations, unless otherwise provided by law, the Civil Code rules listed in the Labour Code shall apply. The legislation of the Civil Code which may be used from the point of view of the Labour Code was codified into the Labour Code in detail; as well as the Civil Code is considered selectively as an underlying or supplementary law. Several labour law institutions have a strong Civil Law character (liability for damages), and several civil law rules are incorporated into the Introductory Provisions. Thus, due to the specific nature of the main service which forms the subject of employment relationship, labour law is indeed a separate branch of law, a relatively independent, mixed special law, part

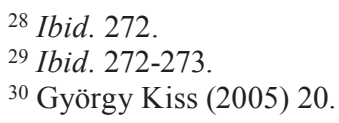

${ }^{29}$ Ibid. 272-273.

${ }^{30}$ György Kiss (2005) 20. 
of private law within the legal system, having stronger civil law relations than those of the Act I of 2012.

The Act CCLII of 2013 reopened one of the long-standing issues of Hungarian labour law. By amending the Labour Code, this Act defines amongst other things, the applicable labour law rules of the Civil Code. As a result of the amendment, Sections 9, 31, 160, 177, 228-229. and 286 contain such referring rules. By reviewing these rules, it can be stated that these are provisions (mainly of the law of obligation) applicable without hindrance in employment relationship law. A related problem is the scope of the General Provisions of the Labour Code. These are also mainly applicable in individual employment relationship, in particular the general rules of conduct, partly by adopting the Civil Code rules of the same content. Sections 6.1 and 6.3 and Sections 8-11 of the Labour Code explicitly refers to this by mentioning employment relationship or parties in employment relationship. There is no doubt that the Labour Code does not provide clearly (specifically) for the application of the rules of civil law in collective labour law, in particular in collective agreement law. This is why the question arises whether the rules of civil law shall apply (in particular) to collective agreements. In the absence of related provisions of the Labour Code, in connection with the application of the civil law rules, the former Hungarian judicial practice established the above mentioned principle that "if a civil law principle or norm does not conflict with the principles of labour law, it shall apply to labour law." According to Gyula Berke and György Kiss, this labour law principle must be applied for collective bargaining even after the Labour Code enters into force. The reason for this is that the Labour Code does not contain any rules referring to this, in other words: the legislator - unlike employment relationship - did not want to make provision for such a thing. On the other hand, collective agreements, although having norm content, carry the characteristics of contractual obligations, too. There is no doubt that the situation created by the the Labour Code entering into force may be difficult for the judicial practice because, as in the case of the employment relationship under the scope of the Labour Code of 1992, the court will be forced to decide case by case on matters not regulated in the Labour Code whether the applicable civil law principle or rule is contrary to labour law or not. ${ }^{31}$

\section{ON THE UNIQUE SYSTEM OF NORMS}

The unique system of labour law norms in Hungarian law clearly indicates how the legislator tries to strengthen the individual self-governance of the parties in labour law legislation despite the presence of public law elements. Freedom of

${ }^{31}$ Gyula Berke, György Kiss: Commentary on the Labour Code, (Kommentár a Munka Törvénykönyvéhez), Wolters Kluwer Kft., (2015) 
contract therefore is also provided in labour law. As defined in the Fundamental Law, everyone shall have the right to freely choose his or her work, occupation. The parties have an influence on shaping the legal relationship since, in the absence of a different provision of the law on the basis of Section 43.1 of the Labour Code, the employment contract may derogate from the individual labour law rules and from the related employment relationship rule in favour of the employee. Pursuant to Section 43.2, derogations must be assessed by comparing the related provisions. The derogatory agreement laid down in the Labour Code includes when the parties' agreement cannot derogate from the provisions of the Labour Code. According to the Explanatory Memorandum, in the context of interrelated provisions, the rules as well as the elements of agreement of the same purpose are to be understood (the raisin principle, Rosienentheorie, does not apply, in line with the judicial practice). The limitations of contractual freedom are, however, the cogent provisions, the individual, relative, dispositive labour law rules where derogation to the disadvantage of the employee is limited or limitless, and the collective agreement can only be derogated from based on the welfare principle. ${ }^{32}$ The basic rules of labour law are the terms and conditions of employment in accordance with Section 13 of the Labour Code: laws (acts, exceptionally and supplementarily a government decree, possibly a ministerial decree), collective agreements and works agreements and binding decisions of the conciliation committee pursuant to Section 293. The normative parts of the latter three are classified as terms and conditions of employment. ${ }^{33}$ The quasi legal norms on employment are collective agreements which are created on a consensual basis as a private law contract but become effective as a law, that is, have a dual legal nature. Works agreements are agreements between works council and employer which may include terms and conditions of employment if the employer does not fall under a collective agreement or there is no trade union to enter into a collective agreement. Binding decisions of the conciliation committee governed by Section 293 of the Labour Code are when the employer and the works council or the trade union may agree in advance to accept the decision of the committee. In this case, the committee's decision is binding. In the event of a tie, the chairperson's vote shall be decisive.

György Kiss points out that the content of the employment contract depends solely on the agreement of the contracting parties (legal fact), while its legal effect, i.e. employment relationship is influenced by a number of factors. These are legislatorial sources of law. That is, we find that employment contracts and employment relationship have differences in content: while employment contracts vary according to the economic environment, the content of employment relationship is, as

32 (ed. Tamás Gyulavári), Labour Law, (Munkajog), Budapest, ELTE Eötvös Kiadó 2013, 59-60.

${ }^{33}$ Ibid. 53. 
a matter of principle, constant. It would be important to deal with legal facts and legal effects holistically. ${ }^{34}$

It can be seen, therefore, that the contract of employment implies the possibility of the fulfilment of individual self-governance, making it flexible in accordance with the economic changes. The contract of employment, however, is not a source of law, according to the prevailing labour law.

The contract of employment, though it fosters employment relationship, is not a rule on employment because it contains rights and obligations for both parties. ${ }^{35}$

Employer regulations are not a rule on employment, either, although labour law literature sees a growing number of publications on the various unilateral legal acts of the employer. As they are becoming increasingly important in practice: there are regulatory (normative) legal declarations and individual legal declarations. ${ }^{36}$

György Kiss, however, approaches the question in a different way: the legal source system of labour law is distinctly different from other branches of law due to the distinct legal nature of some legal source elements. Perhaps the most characteristic feature of labour law legal source system is the duality of sources. $\mathrm{He}$ distinguishes between legislatorial and contractual sources of law (collective bargaining agreements: collective agreements and works agreement). Because of the normative content of the collective agreement, it could be part of the legislatorial legal source system, but on a dogmatic basis it is not, and its relation to legal norms is derived from the general concept of validity of contracts. In the European labour law, individual employment contract is at the top of the contractual hierarchy. An employment contract cannot contain a less favourable condition for the employee than what is laid down in the collective agreement. This is the welfare principle (Günstigkeitsprinzip) ${ }^{37}$ That is, the employment contract is a source of law, too: a contractual source of law.

\section{EMPLOYMENT CONTRACTS AS CONTRACTUAL SOURCES OF LAW?}

What does it mean to us that employment contracts are a contractual source of law? Here I quote László Kelemen's idea about obligation and contracts:

"As for its nature, obligation is a dynamic and organic phenomenon, it is to attain a specific goal, to create a certain future change, and if it fulfills its function, it ceases to exist as if it has never existed. After its termination, it immediately re-emerges and, therefore, it appears to be a short-lived, passing phenomenon

\footnotetext{
${ }^{34}$ György Kiss (2017) 270.

35 Tamás Gyulavári (2013) 53.

${ }^{36}$ György Kiss (2017) 269.

${ }^{37}$ György Kiss (2017) 268-269.
} 
compared to substantive rights which seem to have a continuous existence; it has a beginning, an end and a life-span which includes various moments just like living creatures. By obligation new subject rights come into being which have never existed and could never exist without it, people who have never been in a close legal relationship with each other and who develop a pressing relationship which is usually not only favourable to one or to the other, but mutual, and in some respect, namely in relation to the dispositive legislation, rights and obligations are created which are stronger than law. This phenomenon is called an obligation shoot, which is the most zealous source of the contract." 38 According to László Kelemen, a contract is therefore a lex contractus, a real source of law, when material right enables human self-determination to create law..$^{39}$ In the field of civil law, this individual self-governance indeed widely prevails ${ }^{40}$, whereby legal entities themselves shape the law to legally unregulated relations of life and to some parts of them which are not arranged. In labour law, the legislative power of individuals must be re-discovered in employment contracts, to which it is essential to enforce the principle of partnership.

Section 13 of the Labour Code also establishes a hierarchy of the rules on employment, and the said hierarchy is broken by the principle of more favourable treatment for the employee, which means relatively cogent and relatively dispositive rules in civil law. At the same time, the regulatory technique of the Labour Code clearly demonstrates a respect for the principle of freedom of contract and the promotion of self-governance.

This is evidenced by the fact that the Labour Code has made absolute dispositivity the main rule (bilateral, tariff dispositivity) in contrast to the relative dispositive rule of the old Labour Code. Part 2 of the Labour Code is relatively dispositive for the employment contract. The parties may otherwise agree on any matter which is not a cogent provision. According to the Explanatory Memorandum, this solution addresses the traditional feature of the world of work that, at the level of individual agreements, the equilibrium position of the parties does not prevail, which is the legal reason for dominance of dispositive rules in the traditional system of private law. Thus with regard to the contract of employment, the Labour Code and the collective labour law agreements fix the minimum standards, from which the parties' agreement may differ in favour of the employee in a positive direction. Parts 2 and 3 of the Labour Code is dispositive for the collective agreement. Derogation to the disadvantage of an employee is possible only if the Labour Code allows it. This is to increase the role of collective agreements as a contractual source of law. The same applies to works agreements with a nor-

\footnotetext{
${ }^{38}$ László Kelemen (1941) 7-8.

${ }^{39}$ Ibid. 8.

${ }^{40}$ Ibid.
} 
mative scope. Only wage bargaining, that is, the remuneration of work is an exception. The rest of the Labour Code, Parts 1, 4, 5 and the Closing Provisions are cogent. Derogation is only allowed if expressly permitted by law. Unilateral derogation, relative dispositivity (relative cogency) is common, when derogation is only allowed for the benefit of the employee. These are typically the rules of liability for damages. Limited bilateral dispositivity allows derogation to the employee's disadvantage only to a certain extent. The limit for extraordinary working time is 250 hours a year, from which collective agreements may derogate up to a maximum of 300 hours per year. Exceptions to the main rule of absolute dispositivity are found in the Derogatory Agreement at the end of each chapter. ${ }^{41}$

It can be seen, therefore, that the regulatory technique of the Labour Code provides the opportunity for the principle of contractual freedom to prevail in labour law, even though the protection of the weaker party requires the legislator to make cogent and public law rules.

The present study does not have a profound analysis of the dogmatics of the employment contract, but it is clear that the examination of the relationship between labour law and civil law raises the distinction between the contractual and legislatorial sources of labour law, as labour law regulations increasingly approach civil law rules during employment crises. A contract of employment can become a zealous source of obligation if the parties can flexibly shape the content of the legal relationship. Accordingly, while employment contracts vary according to the economic environment, the content of employment relationship is, as a matter of principle, constant. This is how the uniform management of legal facts and of legal effects is realized.

${ }^{41}$ Tamás Gyulavári (2013) 57. 
Др Нора И. Јакаб, ванредни иррофесор

Универзийети у Мищколиу

Правни факулитети

jakabn81@gmail.com

\section{Значај принципа аутономије воље субјеката радног односа у радном праву}

Сажжейак: Према стиаву Келемен Ласла, уг̄овор је закон за уг̄оворне сииране онда када матиеријално ирраво омогуућава субјекииима ирравног̄ односа да сами, својом вољом, регуулищу иррава, обавезе и одгооворносиии из ииог̄ односа. Та ауйономија воље субјекайа йравног̄ односа одлика је гррађанског̄ иррава, чији инстиитиуйи су йостиављени тиако да субјекиии сами уређују своје међусобне односе. Са друг̄е стиране, йаква ауйономија субјекайа радног̄ односа није одлика инстиитиуйа радног иррава, ири чему, смайрамо да је неойходно редефинисайи йийање ауйономије воље субјекайа овог̄ односа, а све на бази ирриниийа йарйнерстива.

Глава ХІІІ Закона о раду Мађарске одређује хијерархију акайа који се иримењују на радне односе, ири чему, сходно иринцийу in favorem laboratoris, айсолуйну ирредности у иримени даје оним акииима који су иоовољнији за зайослене. Са друг̄е ситране, истии закон, јасно одређује слободу уг̄оварања као кључни йринций у регуулисаюу иррава, обавеза и одг̄оворностии из радног̄ односа, щйио све доводи до својеврсне дилеме у йог̈леду иравне ирироде овог̄ йравног̄ односа.

Имајући у виду све наведено, у овом чланку насиоојимо да дођемо до одг̄овора уйраво на иййање йравне йрироде радног̄ односа, ослањајући се на релеванйне одредбе Закона о раду Мађарске и сйавове иравне иетерије.

Кључне речи: ауйономија воља субјекайа радног̄ односа, флексигуур-

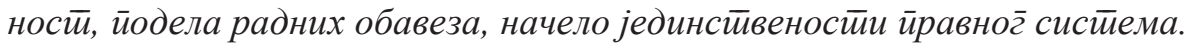

Датум пријема рада: 27.08.2018. 